\title{
Biomaterials
}

\section{Large-scale gene expression analysis of osteoblasts cultured on three different Ti-6Al-4V surface treatments}

\author{
Ching-Hsin $\mathrm{Ku}^{\mathrm{a}}{ }^{\mathrm{b}}$, Martin Browne ${ }^{\mathrm{b}}$, Peter J. Gregson ${ }^{\mathrm{b}}$, Jacques Corbeil ${ }^{\mathrm{d}}$, \\ Dominique P. Pioletti ${ }^{\mathrm{a}, \mathrm{c}, *}$ \\ a Bone Bioengineering Group, Institute for Biomedical Engineering, Swiss Federal Institute of Technology, Lausanne, Switzerland \\ ${ }^{\mathrm{b}}$ Bioengineering Sciences Research Group, School of Engineering Sciences, University of Southampton, Southampton, UK \\ ${ }^{\mathrm{c}}$ Orthopaedic Hospital, Lausanne, Switzerland \\ ${ }^{\mathrm{d}}$ Department of Medicine, University of California, San Diego and San Diego Veterans Affairs, Healthcare System, La Jolla, USA
}

Received 24 October 2001

\begin{abstract}
To improve implant biocompatibility, we developed a simple cost-effective thermal surface treatment allowing an increase in the oxide layer thickness of a titanium (Ti) alloy used in orthopaedic implants. The goal of this study was to test in vitro the reaction of osteoblasts to the developed surface treatment and to compare it to the osteoblast reaction to two other surface treatments currently used in the practice of implant surgery. Quantification of osteoblast gene expression on a large scale was used in this study. The kinetics of gene expression over $120 \mathrm{~h}$ was followed for 58 genes to quantify the effect of the developed surface treatment. Twenty eight genes were further selected to compare the effects of surface treatments on osteoblasts. Based on the genes studied, we could propose a general pathway for the cell reaction according to the surface treatments used: (1) metal ion release changes the time course of gene expression in the FAK pathway; (2) once the accumulation of metal ions released from the Ti surface exceeds a threshold value, cell growth is diminished and apoptosis may be activated; (3) PTK up-regulation is also induced by metal ion release; (4) the expression of Bcl-2 family and Bax may suggest that metal ions induce apoptosis. The developed treatment seems to increase the $\mathrm{Ti}-6 \mathrm{Al}-4 \mathrm{~V}$ biocompatibility as highlighted by the lower impact of this treatment by the different pathways studied, on the lower inflammatory reaction that could be induced, as well as by the lower induced osteoblast apoptosis compared to the two other surface treatments. (C) 2002 Elsevier Science Ltd. All rights reserved.
\end{abstract}

Keywords: Osteoblast; Implant; Surface treatment; Gene expression; Apoptosis; cDNA microarray

\section{Introduction}

When an implant is inserted into bone, it is expected that an apposition of bone to the implant will occur, a process called osteointegration [1]. From histological examinations it has been found that implant loosening is generally associated with the formation of fibrous tissue at the bone-implant interface [2].

It has been hypothesized that the differentiation process of the peri-implant tissue could be driven either by unfavourable mechanical situations [3] or by inflammatory reactions following the phagocytosis of wear particles [4] or by a combination of both [5]. We

*Corresponding author. Institute for Biomedical Engineering, Bat AAB, EPFL, 1015 Lausanne, Switzerland. Tel.: +41-21-693-8341; fax: +41-21-693-8660.

E-mail address: dominique.pioletti@epfl.ch (D.P. Pioletti). recently showed that wear particles also influence osteoblast behaviour [6-9]. Release of metal ions by the implant and their effect on osteoblasts has been mostly neglected until recently [10]. Due to the faster process of ion released compared to wear particles generation, interaction of osteoblast-ion would be important to quantify as this phenomenon occurs soon after prosthesis implantation.

To improve implant biocompatibility, we developed a simple, cost-effective thermal surface treatment allowing an increase in the oxide layer thickness of a titanium alloy used for orthopaedic implants [11,12]. This oxide layer acts as a barrier to keep ions from being released into the body. Kinetic analysis showed a decrease in ion release in the developed surface treatment [13].

Information on Ti-6Al-4V alloy treated surfaces affecting osteoblasts is limited. The goal of this study is then to test the osteoblast reaction to the developed 
surface treatment and to compare it to the osteoblast reaction to two other surface treatments currently used in the practice of orthopaedic implant surgery. The strategy of this study is to perform a large-scale analysis of gene expression in order to highlight possible regulation pathways differentiated by the surface treatments.

\section{Materials and methods}

\subsection{Ti alloy surface preparations}

Distal sections of forged Ti-6Al-4V alloy femoral stems from the Ti-Mod Freeman hip implant were supplied by Finsbury Instruments (Leatherhead, Surrey, UK). The hip stems were cut into discs of $10 \mathrm{~mm}$ diameter and of $1 \mathrm{~mm}$ thickness. The samples were polished following a previously described procedure [14]. The samples were then cleaned in $1 \%$ Triton solution for $1 \mathrm{~h}$ and rinsed in deionized distilled water. This treatment was used as control (C). The practice for surface preparation of surgical implants involves a nitric acid passivation treatment $(\mathrm{P})$ with an immersion of the


third treatment that we called aged treatment (A), which consisted of the passivated treatment followed by ageing in boiling deionized distilled water for $10 \mathrm{~h}[11,12]$. The samples were then sterilized and tested for endotoxin contamination [14].

\subsection{Cell culture}

Primary human osteoblasts (hOB) were isolated from pieces of cortical bone femur obtained during total hip arthroplasty of a female patient $(62 \mathrm{yr})$ following a procedure previously described [16]. The osteoblastic cells were cultured in Dulbecco's modified Eagle's medium (Sigma, Buchs, Switzerland) containing 10\% fetal bovine serum (Sigma), 1\% PSF $(100 \times, 10,000 \mathrm{U} /$ $\mathrm{ml}$ Penicillin, $10,000 \mathrm{mg} / \mathrm{ml}$ Streptomycin and $25 \mathrm{mg} / \mathrm{ml}$ Fungizone) (GibcoBRL, Life Technologies, Basel, Switzerland) under a humidified $5 \% \mathrm{CO}_{2} /$ air atmosphere at $37^{\circ} \mathrm{C}$. Osteoblasts passages lower than 4 were used for the study. The osteoblasts were seeded at a concentration of 380,000 cells $/ \mathrm{cm}^{2}$ on each sample. In order to have enough material to study gene expression, 6 samples of each treated surface were used (total cells number: $1.62 \times 10^{7}$ ).

\subsection{Gene expression study}

Genefilters GF211 (Research Genetics, Huntsville, AL, USA) were used to monitor the expression of 12,626 genes. The collected RNA from the cells $(5 \mathrm{mg}$ of total RNA per condition) was processed according to the manufacturer's recommendations. The Pathways software, developed by Research Genetics was used to acquire the Genefilters data. Normalization of gene expression and data analysis was performed using Excel (Microsoft Corporation, Redmond, WA, USA) and 2HAPI, a web-based bioinformatics software (http:// array.sdsc.edu). The kinetics of gene expression for hOB incubated with the aged $\mathrm{Ti}-6 \mathrm{Al}-4 \mathrm{~V}$ was measured at 4 , 24,48 and $120 \mathrm{~h}$. The gene expression of cells incubated $4 \mathrm{~h}$ on the aged sample $\left(\mathrm{A}_{4}\right)$ was chosen as the reference. 58 genes were selected and classified in 6 groups according to adhesion, signal pathway and transcription factors, growth factors and cytokines, differentiation, mineralization and apoptosis. This selection represents a panel of major genes expressed by osteoblasts $[17,18]$.

Twenty-eight genes were specifically analysed to compare the difference in gene expression between different surface treatments. The results are presented as the ratio of $\mathrm{P} / \mathrm{A}$ and $\mathrm{C} / \mathrm{A}$ for the corresponding gene expression.

For both analyses, the difference in gene expression is based on the experimental finding that upregulation by a ratio higher than 2.5 -fold or down-regulation by a ratio lower than 0.4 -fold $(=1 / 2.5)$ has to be reached to be considered as significant. Sample control at $24 \mathrm{~h}$ was analysed twice with two filters $\left(\mathrm{C}_{24(1)}\right.$ and $\left.\mathrm{C}_{24(2)}\right)$ and showed good reproducibility $(70 \%$ of the gene tested had a gene expression variation lower than $10 \%$ between the two analysis) (data not shown).

\section{Results}

The results presented in Table 1 are intended to evaluate the kinetics of gene modulation of the surface treatment A, while results presented in Table 2 are used to compare gene expression with respect to the different surface treatments $(\mathrm{C}, \mathrm{P}, \mathrm{A})$. The functional description of the chosen genes is given in Table 3 . Sample $\mathrm{A}_{24}$ did not have enough RNA for the analysis.

\subsection{Kinetics of genes modulation by the surface treatment $A$ (Table 1)}

From a quantitative point of view, in comparison with $\mathrm{A}_{4}, \mathrm{~A}_{48}$ has 213 up-regulated genes and 5 downregulated genes; $A_{120}$ has 247 up-regulated genes and 5 down-regulated genes. More specifically, 58 genes were selected and described in the following groups.

\subsubsection{Adhesion}

Collagen alpha-2 type I was up regulated 4.4-fold at $48 \mathrm{~h}$ and 3.48 -fold at $120 \mathrm{~h}$ compared to $\mathrm{A}_{4}$. Integrin $\alpha_{3}, \alpha_{5}, \alpha_{6}, \beta_{1}, \beta_{5}$, and fibronectin were expressed by the isolated hOB, but did not show a significant difference compared to $\mathrm{A}_{4}$. 
Table 1

Kinetic of gene expression for the aged $\mathrm{Ti}-6 \mathrm{Al}-4 \mathrm{~V}$ surface ( 58 genes)

\begin{tabular}{|c|c|c|c|}
\hline Acc & Gene name & $\mathrm{A}_{48} / \mathrm{A}_{4}$ & $\mathrm{~A}_{120} / \mathrm{A}_{4}$ \\
\hline & Adhesion & & \\
\hline U70312 & Homo sapiens integrin binding protein Del-1 (Del1) mRNA & 1.32 & 0.98 \\
\hline M59911 & Human integrin alpha-3 chain mRNA & 0.87 & 1.76 \\
\hline X06256 & Human mRNA for integrin alpha 5 & 0.81 & 0.69 \\
\hline X53586 & Human mRNA for integrin alpha 6 & 0.93 & 0.84 \\
\hline X07979 & Human mRNA for integrin beta 1 & 0.55 & 0.79 \\
\hline M35011 & Human integrin beta- 5 mRNA & 0.80 & 0.79 \\
\hline X53002 & Human mRNA for integrin beta- 5 & 0.68 & 0.61 \\
\hline X02761 & Human mRNA for fibronectin (FN precursor) & 1.10 & 1.26 \\
\hline M10905 & Human cellular fibronectin mRNA & 1.14 & 1.42 \\
\hline \multirow[t]{2}{*}{ J03464 } & Human collagen alpha- 2 type I mRNA & 4.40 & 3.48 \\
\hline & Signal pathway and transcription factors & & \\
\hline L13616 & Human focal adhesion kinase (FAK) mRNA & 0.16 & 0.73 \\
\hline Z11695 & Homo sapiens $40 \mathrm{kDa}$ protein kinase related to rat ERK2 (MAPK1, MAPK2) & 0.52 & 0.72 \\
\hline X80692 & Cluster Incl X80692: Homo sapiens ERK3 mRNA (MAPK6) & 0.49 & 0.41 \\
\hline AF002715 & Cluster Incl AF002715:Homo sapiens MAP kinase kinase kinase (MTK1) & 0.33 & 0.46 \\
\hline D87116 & Human mRNA for MAP kinase kinase $3 \mathrm{~b}$ & 0.22 & 0.23 \\
\hline J04111 & Human c-jun proto oncogene (JUN), clone hCJ-1 & 0.43 & 0.63 \\
\hline V01512 & Human cellular oncogene c- $f o s$ & 2.23 & 1.52 \\
\hline U02680 & Human protein tyrosine kinase mRNA (PTK9) & 0.50 & 0.63 \\
\hline M59371 & Human protein tyrosine kinase (PTK) mRNA (EPHA2) & 3.20 & 9.09 \\
\hline \multirow[t]{2}{*}{ AF015254 } & Homo sapiens serine/threonine kinase (STK-1) mRNA & 10.10 & - \\
\hline & Growth factors and cytokines & & \\
\hline M37825 & Human fibroblast growth factor-5 (FGF-5) mRNA & 5.85 & 6.37 \\
\hline M60828 & Human keratinocyte growth factor $(\mathrm{KFG}=\mathrm{FGF}-7)$ mRNA $(3853 \mathrm{bp})$ & 1.33 & 2.80 \\
\hline X03563 & Human gene for Insulin-like growth factor I & 4.38 & - \\
\hline M77349 & Human transforming growth factor-beta-induced gene product (BIGH3) & 1.31 & 0.82 \\
\hline X06374 & Human mRNA for platelet-derived growth factor PDGF-A & 1.41 & 1.83 \\
\hline M22488 & Human bone morphogenetic protein 1 (BMP-1) mRNA & 0.79 & - \\
\hline M22489 & Human bone morphogenetic protein $2 \mathrm{~A}(\mathrm{BMP}-2 \mathrm{~A})$ mRNA & - & - \\
\hline M22490 & Human bone morphogenetic protein-2B (BMP-2B) mRNA & 0.76 & - \\
\hline U43842 & Homo sapiens bone morphogenetic protein-4 (hBMP-4) gene & 0.43 & 0.57 \\
\hline M27968 & Human basic fibroblast growth factor (bFGF) mRNA & 0.52 & 0.61 \\
\hline \multirow[t]{2}{*}{ M28983 } & Homo sapiens interleukin 1 alpha (IL-1) mRNA & - & - \\
\hline & Differentiation & & \\
\hline J04948 & Human alkaline phosphatase (ALP-1) mRNA & 1.22 & 1.34 \\
\hline L40992 & Homo sapiens core-binding factor, runt domain, alpha subunit 1 (CBFA1) & - & - \\
\hline L38517 & Homo sapiens indian hedgehog protein $(\mathrm{IHH}) \mathrm{mRNA}, 5^{\prime}$ end & - & - \\
\hline \multirow[t]{2}{*}{ AF009801 } & Homo sapiens homeodomain protein (BAPX1) mRNA & - & - \\
\hline & Mineralization & & \\
\hline J03040 & Human SPARC/osteonectin mRNA & 1.76 & 1.49 \\
\hline J04765 & Human osteopontin mRNA & 0.86 & - \\
\hline J04599 & Human hPGI mRNA encoding bone small proteoglycan I (biglycan) & 1.42 & 1.82 \\
\hline \multirow[t]{2}{*}{ J05213 } & Homo sapiens sialoprotein precursor (IBSP) mRNA & - & - \\
\hline & Apoptosis & & \\
\hline U37518 & Human TNF-related apoptosis inducing ligand TRAIL mRNA & - & - \\
\hline AF014794 & Homo sapiens TNF related TRAIL receptor (TRAIL-R3) mRNA & - & - \\
\hline M58603 & Human NF- $\kappa$ B DNA binding subunit (NF-kappa-B) mRNA (NF- $\kappa$ B1) & 0.85 & 0.92 \\
\hline L19067 & Human NF- $\kappa$ B transcription factor p65 subunit mRNA (Rel A) & 0.69 & 0.83 \\
\hline AF018253 & Homo sapiens receptor activator of nuclear factor-kappa B (RANK) mRNA & - & - \\
\hline AF022385 & Homo sapiens apoptosis-related protein TFAR15 (TFAR15) & 0.52 & 0.41 \\
\hline Y11588 & Homo sapiens mRNA for apoptosis specific protein & - & - \\
\hline AF053712 & Homo sapiens osteoprotegerin ligand mRNA (TRANCE) & - & - \\
\hline M37435 & Human macrophage-specific colony-stimulating factor (M-CSF) & 0.90 & 0.56 \\
\hline M13207 & Human granulocyte-macrophage colony-stimulating factor gene (GM-CSF) & - & - \\
\hline X03656 & Human gene for granulocyte colony-stimulating factor $(\mathrm{G}-\mathrm{CSF}=\mathrm{CSF}-3)$ & - & - \\
\hline M14745 & Human bcl-2 mRNA (BCL2 (B-cell CLL/lymphoma 2)) & - & - \\
\hline
\end{tabular}


Table 1 (continued)

\begin{tabular}{|c|c|c|c|}
\hline Acc & Gene name & $\mathrm{A}_{48} / \mathrm{A}_{4}$ & $\mathrm{~A}_{120} / \mathrm{A}_{4}$ \\
\hline M13994 & $\begin{array}{l}\text { Human B-cell leukemia/lymphoma } 2 \text { (bcl-2) proto-oncogene mRNA encoding bcl-2- } \\
\text { alpha protein (BCL2 (B-cell CLL/lymphoma 2)) }\end{array}$ & - & 0 \\
\hline M13995 & $\begin{array}{l}\text { Human B-cell leukemia/lymphoma } 2 \text { (bcl-2) proto-oncogene mRNA encoding bcl-2- } \\
\text { beta protein }\end{array}$ & - & - \\
\hline Z23115 & Homo sapiens bcl-xL mRNA & 6.42 & 10.08 \\
\hline L22473 & Human Bax alpha mRNA & 1.12 & 0.68 \\
\hline L22474 & Human Bax beta mRNA & 1.32 & - \\
\hline L22475 & Human Bax gamma mRNA & 0.47 & - \\
\hline U19599 & Human Bax delta mRNA & 0.99 & 0.67 \\
\hline
\end{tabular}

The column $\mathrm{A}_{48} / \mathrm{A}_{4}$, represents the gene expression of osteoblasts seeded $48 \mathrm{~h}$ on aged sample divided by the gene expression of osteoblasts seeded $4 \mathrm{~h}$ on aged sample. Similar nomenclature is used for the other columns. "_-" means that no signal was measured. The value in bold type means significant expression ( $\geqslant 2.5$-fold: up-regulation; $\leqslant 0.4$-fold: down-regulation). Acc is the Genebank accession number.

\subsubsection{Signal pathways and transcription factors}

Focal adhesion kinase (FAK) and mitogen-activated protein (MAP) kinases were down-regulated at 48 and $120 \mathrm{~h}$. c-jun showed a 0.43 -fold decrease and c-fos was increased 2.23-fold for $\mathrm{A}_{48}$. Protein tyrosine kinase (PTK9) showed a 0.5 -fold decrease at $48 \mathrm{~h}$. PTK receptor was upregulated 3.20 -fold at $48 \mathrm{~h}$ and increased with time. Stem cell tyrosine kinase 1 (STK-1) was upregulated 10.10 -fold at $48 \mathrm{~h}$ but undetected at $120 \mathrm{~h}$.

\subsubsection{Growth factors and cytokines}

FGF-5 was up-regulated 5.85-fold and increased to 6.37 -fold at $120 \mathrm{~h}$. Keratinocyte growth factor $(\mathrm{KGF}=\mathrm{FGF}-7)$ was up-regulated 2.8 -fold at $120 \mathrm{~h}$. Insulin-like growth factor (IGF-1) was up-regulated 4.38 -fold at $48 \mathrm{~h}$ and not detected at $120 \mathrm{~h}$. Transforming growth-factor- $\beta$-induced gene (BIGH3) and plateletderived growth factor (PDGF-A) were detected, but did not show significant modulation. Most of the BMPs were not detected (BMP-2A, BMP-3 and BMP-5, data not shown) or down-regulated (BMP-1, BMP-2B and BMP-4). Genes, which have been proved to be involved in the process of osteoporosis, such as basic fibroblast growth factor, (FGF-2 or bFGF) and interleukin 1 alpha (IL- $1 \alpha$ ) were either absent or down-regulated compared to the reference $\mathrm{A}_{4}$. The expression of proinflammatory mediators including IL-6 and prostaglandin E-2 (PGE-2) were not detected (data not shown).

\subsubsection{Differentiation}

No significant gene expression for core-binding factor runt domain alpha subunit 1 (cbfa1), Indian hedgehog (IHH) and homeodomain (BAPX1) was observed, except for alkaline phosphatase (ALP), which had a 1.22 -fold increase at $48 \mathrm{~h}$ and a 1.45 -fold increase at $120 \mathrm{~h}$.

\subsubsection{Mineralization}

SPARC/osteonectin, osteopontin (OPN), and biglycan (bone matrix glycoproteins), which are involved in bone matrix mineralization, were detected. SPARC had a 1.76-fold increase, OPN showed a 0.86 -fold decrease and biglycan showed a 1.42-fold increase at $48 \mathrm{~h}$. Sialoprotein precursor (IBSP) was absent.

\subsubsection{Apoptosis}

$\mathrm{NF}-\kappa \mathrm{B} 1$ showed a 0.85 -fold decrease at $48 \mathrm{~h}$ and $0.92-$ fold decrease at $120 \mathrm{~h}$. NF- $\kappa \mathrm{B}$ p 65 showed a 0.69 -fold decrease at $48 \mathrm{~h}$ and a 0.83 -fold decrease at $120 \mathrm{~h}$. The apoptosis related protein, TFAR15, showed a 0.52 -fold decrease at $48 \mathrm{~h}$ and a down-regulation of 0.41 -fold at $120 \mathrm{~h}$. Bcl-xL was up-regulated 6.42 -fold at $48 \mathrm{~h}$ and upregulated 10.08 -fold at $120 \mathrm{~h}$. Bax isoform (alpha, beta, gamma and delta) decreased over time.

\subsection{Comparison of gene expression with respect to the surface treatments $C, P, A$ (Table 2)}

In order to determine differential hOB gene expression from various treated surfaces, 28 genes were selected from Table 1 and described in the following groups.

\subsubsection{Adhesion}

Collagen alpha-2 type I expression increased by 1.45 and 1.18-fold for samples $\mathrm{P}_{48}$ and $\mathrm{C}_{48}$ compared to $\mathrm{A}_{48}$, and decreased by 0.70 - and 0.74 -fold for samples $\mathrm{P}_{120}$ and $\mathrm{C}_{120}$ compared to $\mathrm{A}_{120}$, respectively.

\subsubsection{Signal pathways and transcription factors}

FAK was up-regulated 4.25- and 6.63-fold for samples $\mathrm{P}_{48}$ and $\mathrm{C}_{48}$ compared to $\mathrm{A}_{48}$. MAPK6 was up-regulated 2.59-fold for sample $\mathrm{C}_{48}$ compared to $\mathrm{A}_{48}$. c-jun increased by 1.84-fold for samples $\mathrm{P}_{48}$ and $\mathrm{C}_{48}$, then decreased over time. c-fos expression was downregulated 0.27 -fold for sample $\mathrm{C}_{48}$ and increased with time for samples $\mathrm{P}$ and C. PTK9 was up-regulated 3.26fold for sample $\mathrm{C}_{48}$ compared to $\mathrm{A}_{48}$. Serine/threonine kinases (STK-1) did not show difference between samples. 
Table 2

Gene expressions between the aged treatment and control and passivated treatments (28 genes)

\begin{tabular}{|c|c|c|c|c|c|}
\hline Acc & Gene name & $\mathrm{P}_{48} / \mathrm{A}_{48}$ & $\mathrm{C}_{48} / \mathrm{A}_{48}$ & $\mathrm{P}_{120} / \mathrm{A}_{120}$ & $\mathrm{C}_{120} / \mathrm{A}_{120}$ \\
\hline & Adhesion & & & & \\
\hline \multirow[t]{2}{*}{ J03464 } & Human collagen alpha-2 type I mRNA & 1.45 & 1.18 & 0.70 & 0.74 \\
\hline & Signal pathways and transcription factors & & & & \\
\hline L13616 & Human focal adhesion kinase (FAK) mRNA & 4.25 & 6.63 & 1.04 & 1.22 \\
\hline Z11695 & $\begin{array}{l}\text { Homo sapiens } 40 \mathrm{kDa} \text { protein kinase related to rat ERK2 } \\
\text { (MAPK1 (mitogen-activated protein kinase 1), MAPK2) }\end{array}$ & 2.32 & 2.17 & 0.85 & 0.76 \\
\hline X80692 & $\begin{array}{l}\text { Cluster Incl X80692:Homo sapiens ERK3 mRNA (MAPK6 } \\
\text { (mitogen-activated protein kinase 6)) }\end{array}$ & 2.48 & 2.59 & 1.60 & 1.01 \\
\hline AF002715 & $\begin{array}{l}\text { Cluster Incl AF002715:Homo sapiens MAP kinase kinase kinase } \\
\text { (MTK1) mRNA }\end{array}$ & 1.14 & 1.14 & 0.93 & 0.69 \\
\hline D87116 & Human mRNA for MAP kinase kinase $3 b$ & 1.14 & 1.46 & 0.86 & 1.24 \\
\hline J04111 & Human c-jun proto oncogene (JUN), complete cds, clone hCJ-1 & 1.84 & 1.85 & 1.09 & 0.69 \\
\hline V01512 & Human cellular oncogene c-fos & 0.78 & 0.27 & 1.91 & 0.42 \\
\hline U02680 & Human protein tyrosine kinase (PTK9) mRNA & 2.16 & 3.26 & 1.54 & 0.81 \\
\hline \multirow[t]{2}{*}{ AF015254 } & Homo sapiens serine/threonine kinase (STK-1) mRNA & 1.30 & 0.89 & 0.84 & 1.48 \\
\hline & Growth factors and Cytokines & & & & \\
\hline X03565 & Human IGF-I mRNA for insulin-like growth factor I & 0.58 & 1.45 & 2.13 & 1.47 \\
\hline M37825 & Human fibroblast growth factor-5 (FGF-5) mRNA & 0.55 & 0.78 & 1.80 & 1.06 \\
\hline S81661 & Keratinocyte growth factor $(\mathrm{KGF}=\mathrm{FGF}-7)$ & 4.90 & 7.07 & 0.79 & 0.62 \\
\hline M60828 & Human keratinocyte growth factor (KFG) mRNA & 2.41 & 2.51 & 0.88 & 0.67 \\
\hline \multirow[t]{2}{*}{ M27968 } & Human basic fibroblast growth factor (bFGF) mRNA & 2.40 & 3.19 & 1.02 & 1.13 \\
\hline & Differentiation & & & & \\
\hline \multirow[t]{2}{*}{ J04948 } & Human alkaline phosphatase (ALP-1) mRNA & - & 0.86 & - & - \\
\hline & Mineralization & & & & \\
\hline J03040 & Human SPARC/osteonectin mRNA & 0.95 & 0.94 & 0.90 & 1.34 \\
\hline \multirow[t]{2}{*}{ J04599 } & Human hPGI encoding bone small proteoglycan I (biglycan) & 0.93 & 0.94 & 0.84 & 1.25 \\
\hline & Apoptosis & & & & \\
\hline M58603 & Human nuclear factor kappa-B DNA binding subunit (NF-кB1) & 1.51 & 1.31 & 0.98 & 0.88 \\
\hline L19067 & Human NF-kappa-B transcription factor p65 subunit (Rel A) & 0.97 & 1.04 & 0.86 & 0.87 \\
\hline AF022385 & $\begin{array}{l}\text { Cluster Incl AF022385:Homo sapiens apoptosis-related protein } \\
\text { TFAR15 (TFAR15) mRNA }\end{array}$ & 2.75 & 2.56 & 1.95 & 1.20 \\
\hline Z23115 & Homo sapiens bcl-xL mRNA & - & - & 0.90 & 0.14 \\
\hline L22473 & Human Bax alpha mRNA & 0.25 & - & 2.25 & 1.99 \\
\hline L22474 & Human Bax beta mRNA & 0.44 & 1.23 & 0.77 & 1.30 \\
\hline U19599 & Human Bax delta mRNA & 0.75 & 0.75 & 1.72 & 1.63 \\
\hline U09477 & $\begin{array}{l}\text { Human clone 53BP1 p53-binding protein mRNA, partial cds } \\
\text { (TP53BP1 (tumour protein p53-binding protein, 1)) }\end{array}$ & - & - & - & - \\
\hline U58334 & $\begin{array}{l}\text { Human Bcl2, p53 binding protein } \mathrm{Bbp} / 53 \mathrm{BP} 2(\mathrm{BBP} / 53 \mathrm{BP} 2) \\
\text { mRNA (TP53BP2 (tumour protein p53-binding protein, 2)) }\end{array}$ & 1.31 & 1.14 & 0.80 & 1.01 \\
\hline M35878 & $\begin{array}{l}\text { Human insulin-like growth factor-binding protein-3 gene } \\
\text { (IGFBP3) }\end{array}$ & 1.18 & 1.08 & 0.65 & 0.96 \\
\hline
\end{tabular}

The column $\mathrm{P}_{48} / \mathrm{A}_{48}$, represents the gene expression of osteoblasts seeded $48 \mathrm{~h}$ on passivated sample divided by the gene expression of osteoblasts seeded $48 \mathrm{~h}$ on aged sample. Similar nomenclature is used for the other columns.

\subsubsection{Growth factors and cytokines}

IGF-I expression decreased by 0.58 -fold for sample $\mathrm{P}_{48}$ and increased by 1.45 -fold for sample $\mathrm{C}_{48}$. FGF-5 decreased at $48 \mathrm{~h}$ and increased at $120 \mathrm{~h}$ for samples $\mathrm{P}$ and $\mathrm{C}$ compared to sample A. Keratinocyte growth factor $(\mathrm{KGF}=\mathrm{FGF} 7)$ was up-regulated 4.90 -fold and 7.07-fold for samples $\mathrm{C}_{48}$ and $\mathrm{P}_{48}$. FGF-2 (bFGF) was up-regulated 3.19-fold for sample $\mathrm{C}_{48}$ and was increased 2.40-fold for $\mathrm{P}_{48}$.

\subsubsection{Differentiation}

ALP was not detected for samples $\mathrm{P}$ and $\mathrm{C}$ during the test.

\subsubsection{Mineralization}

SPARC/osteonectin and biglycan had a 0.95 -fold decrease for samples $\mathrm{P}_{48}$ and $\mathrm{C}_{48}$ compared to sample $\mathrm{A}_{48}$. 
Table 3

The cellular functions of the chosen genes (based on GeneCards http://bioinfo.weizmann.ac.il/cards/ and [31]

\begin{tabular}{lll}
\hline Gene & Genecard & Cellular function \\
\hline $\begin{array}{ll}\text { Integrin } \alpha_{3} \\
\text { Integrin } \alpha_{5}\end{array}$ & ITGA3 & $\begin{array}{l}\text { Adhesion } \\
\text { Acts a receptor for fibronectin, laminin and collagen } \\
\text { Integrin alpha-5/beta-1 is a receptor for fibronectin and fibrinogen. It recognizes the sequence R-G-D in its } \\
\text { ligands }\end{array}$ \\
Integrin $\alpha_{6}$ & ITGA6 & $\begin{array}{l}\text { Integrin alpha-6/beta-4 may mediate adhesive and/or migratory functions of epithelial cells. On platelets, } \\
\text { integrin alpha-6/beta-1 functions as a laminin receptor }\end{array}$ \\
Integrin $\beta_{1}$ & ITGB1 & $\begin{array}{l}\text { Associates with alpha-1 or alpha-6 to form a laminin receptor, with alpha-2 to form a collagen receptor, with } \\
\text { alpha-4 to interact with vcam-1, with alpha-5 to form a fibronectin receptor and with alpha-8. Integrins } \\
\text { recognize the sequence R-G-D in their ligand } \\
\text { Integrin } \beta_{5}\end{array}$ \\
Fibronectin & FN1 & $\begin{array}{l}\text { Integrins are a large family of cell surface glycoproteins that mediate cell to cell and cell to matrix adhesion } \\
\text { Fibronectins bind cell surfaces and various compounds including collagen, fibrin, heparin, DNA, and actin. } \\
\text { fibronectins are involved in cell adhesion, cell motility, opsonization, wound healing, and maintenance of cell } \\
\text { shape }\end{array}$ \\
Type I collagen is a member of group I collagen (fibrillar forming collagen)
\end{tabular}

Collagen $\alpha-2 \quad$ COL1A2

type I

FAK

PTK2

\section{MAPK}

MAPK1

c-jun

c-fos

JUN

FOS

PTK

PTK9

PTK-receptor EPHA2

STK-1 STK12

FGF-2 FGF2

FGF-5 FGF5

FGF-7 FGF7

IGF-I IGF1

TGF- $\beta$ TGFBI,

BIGH3

BMPs BMP4

PDGF-A PDGFA

IL- $1 \alpha \quad$ IL1A

IL-6 IL6

PGE-2 PTGER1

Cbfal RUNX2

IHH IHH

$\begin{array}{ll}\text { BAPX1 } & \text { BAPX1 } \\ \text { ALP } & \text { ALPPL2 } \\ \text { SPARC } & \text { SPARC }\end{array}$

Type I collagen is a member of group I collagen (fibrillar forming collagen)

Signal pathway and transcriptor factors

Activation of focal adhesion kinases (FAK) may be an early step in intracellular signal transduction pathways. This tyrosine-phosphorylation is triggered by integrin interactions with various extracellular matrix (ecm) adhesive molecules and by neuropeptide growth factors. Potential role in oncogenic transformations resulting in increased kinase activity

Phosphorylates microtubule-associated protein-2 (map2). Myelin basic protein (MBP), and elk-1; may promote entry in the cell cycle

Transcription factor that binds and recognize the enhancer DNA sequence: TGA(C/G)TCA

Nuclear phosphoprotein, which forms a tight but non-covalently linked complex with the c-jun/ap-1

transcription factor. c-fos has a critical function in regulating the development of cells destined to form and maintain the skeleton. It is thought to have an important role in signal transduction, cell proliferation and differentiation

Receptor for members of the ephrin-a family. Binds to ephrin-a1, -a3, -a4 and -a5

Growth factor and cytokines

The heparin-binding growth factors are angiogenic agents in vivo and are potent mitogens for a variety of cell types in vitro. There are differences in the tissue distribution and concentration of these 2 growth factors

This oncogene is expressed in neonatal brain. FGF-5 can transform NIH 3T3 cells

Growth factor active on keratinocytes. Possible major paracrine effector of normal epithelial cell proliferation The insulin-like growth factors, isolated from plasma, are structurally and functionally related to insulin but have a much higher growth-promoting activity

Binds to type I, II, and IV collagens. This adhesion protein may play an important role in cell-collagen interactions. In cartilage, may be involved in endochondral bone formation

Induces cartilage and bone formation

Platelet-derived growth factor is a potent mitogen for cells of mesenchymal origin. Binding of this growth factor to its affinity receptor elicits a variety of cellular responses. It is released by platelets upon wounding and plays an important role in stimulating adjacent cells to grow and thereby heal the wound

Produced by activated macrophages, IL-1 stimulates thymocyte proliferation by inducing IL-2 release, B-cell maturation \& proliferation, \& fibroblast growth factor activity. IL-1 proteins are involved in the

inflammatory response, being identified as endogenous pyrogens, and are reported to stimulate the release of prostaglandin and collagenase from synovial cells

It plays an essential role in the final differentiation of b-cells into ig-secreting cells, it induces myeloma and plasmacytoma growth, it induces nerve cells differentiation, in hepatocytes it induces acute phase reactants Receptor for prostaglandin E2 (PGE2). The activity of this receptor is mediated by G-Q proteins which activate a phosphatidylinositol-calcium second messenger system. May play a role as an important modulator of renal function. Implicated the smooth muscle contractile response to PGE2 in various tissues Osteoblast-specific transcription factor

Intercellular signal essential for a variety of patterning events during development. Binds to the patched (PTC) receptor, which functions in association with smoothened (SMO), to activate the transcription of target genes. Implicated in endochondral ossification: may regulate the balance between growth and ossification of the developing bones. Induces the expression of parathyroid hormone-related protein (PTHRP) (by similarity)

Homeo box-containing gene,Drosophila bagpipe homolog, involved in mesodermal and skeletal development Catalytic activity: an orthophosphoric monoester $+\mathrm{h}(2) \mathrm{o}=$ an alcohol + orthophosphate $($ at a high $\mathrm{pH}$ optimum)

Appears to regulate cell growth through interactions with the extracellular matrix and cytokines. Binds calcium and copper, several types of collagen, albumin, thrombospondin, PDGF and cell membranes. There 
Table 3 (continued)

\begin{tabular}{|c|c|c|}
\hline Gene & Genecard & Cellular function \\
\hline & & $\begin{array}{l}\text { are two calcium binding sites; a acidic domain that binds } 5-8 \mathrm{Ca}^{2+} \text { with a low affinity and a ef-hand loop that } \\
\text { binds a } \mathrm{Ca}^{2+} \text { ion with a high affinity }\end{array}$ \\
\hline OPN & SPP1 & $\begin{array}{l}\text { Binds tightly to hydroxyapatite. Appears to form an integral part of the mineralized matrix. Probably } \\
\text { important to cell-matrix interaction }\end{array}$ \\
\hline Biglycan & BGN & $\begin{array}{l}\text { Found in the extracellular matrices of several connective tissues, specially in articular cartilages. The two } \\
\text { glycosaminoglycan chains attached to biglycan can be either chondroitin sulphate or dermatan sulphate }\end{array}$ \\
\hline IBSP & IBSP & $\begin{array}{l}\text { Binds tightly to hydroxyapatite. Appears to form an integral part of the mineralized matrix. Probably } \\
\text { important to cell-matrix interaction. Promotes Arg-Gly Asp-dependent cell attachment }\end{array}$ \\
\hline TRAIL & TNFSF10 & Induces apoptosis \\
\hline $\mathrm{NF}-\kappa \mathrm{B} 1$ & NFKB1 & $\begin{array}{l}\text { P105 is the precursor of the p50 subunit of the nuclear factor NF-kappa-b, which binds to the kappa-b } \\
\text { consensus sequence } 5^{\prime} \text {-ggrnnyycc- } 3^{\prime} \text {, located in the enhancer region of genes involved in immune response and } \\
\text { acute phase reactions. The precursor protein itself does not bind to DNA }\end{array}$ \\
\hline NF-кB p65 & RELA & $\begin{array}{l}\text { p65 is a subunit of the nuclear factor kappa-b, a second messenger, which activates the transcription of a } \\
\text { number of genes in multiple tissues. The inhibitory effect of i-kappa-b upon NF-kappa-b in the cytoplasm is } \\
\text { exerted primarily through the interaction with p65. p65 shows a weak DNA-binding site which could } \\
\text { contribute directly to DNA binding in the NF-kappa-b complex }\end{array}$ \\
\hline OPG & TNFSF11 & $\begin{array}{l}\text { Tumour necrosis factor superfamily, member } 11 \text { TNFRSF11A (RANK) and OPG (osteprogerin ligand), } \\
\text { localized in T cells bone marrow stromal cells, hypertrophic chondrocyte, stimulated by IL1B and } \\
\text { TNFRSF11B,expressed in bone, brain, heart, kidney, skeletal muscle, skin, cooperating with prostaglandin, } \\
\text { mediating osteoclastognesis and bone loss through systemic activation of T cells, regulating lymph node } \\
\text { organogenesis lymphocyte development and interactions between T cells and dendritic cells, activating the } \\
\text { antiapoptotic serine threonine kinase AKT/PKB through a signal complex involving TRAF6 and SRC }\end{array}$ \\
\hline RANK & TNFRSF11A & \\
\hline TRANCE & TNFSF11 & \\
\hline TFAK 15 & PDCD10 & - \\
\hline CSFs & CSF1 & $\begin{array}{l}\text { Granulocyte/macrophage colony-stimulating factors are cytokines that act in hematopoiesis by controlling } \\
\text { the production, differentiation, and function of two related white cell populations of the blood, the } \\
\text { granulocytes and the monocytes-macrophages }\end{array}$ \\
\hline Bcl-2 & $\begin{array}{l}\text { BCL2 (B-cell } \\
\text { CLL/ } \\
\text { lymphoma 2) }\end{array}$ & $\begin{array}{l}\text { Prolongs the survival of hematopoietic cells in the absence of required growth factors and also in the presence } \\
\text { of various stimuli inducing cellular death. Bcl } 2 \text { blocks apoptosis because it interferes with the activation of } \\
\text { caspases by preventing the release of cytochrome } c \text {. might function in an antioxidant pathway to prevent } \\
\text { apoptosis at sites of free radical generation such as mitochondria }\end{array}$ \\
\hline Bcl-xL & BCL2L1 & $\begin{array}{l}\text { Dominant regulator of apoptotic cell death. The long form displays cell death repressor activity, whereas the } \\
\text { short isoform (-xS) promotes apoptosis }\end{array}$ \\
\hline Bax & BAX & $\begin{array}{l}\text { Accelerates programed cell death by binding to, and antagonizing the apoptosis repressor bcl- } 2 \text { or its } \\
\text { adenovirus homolog e } 1 \mathrm{~b} 19 \mathrm{k} \text { protein. Induces the release of cytochrome } c \text {, activation of caspase- } 3 \text {, and } \\
\text { thereby apoptosis }\end{array}$ \\
\hline ТР53ВP2 & ТР53ВP2 & Impedes cell cycle progression at $\mathrm{G} 2 / \mathrm{M}$ \\
\hline IGF-BP3 & IGFBP3 & $\begin{array}{l}\text { IGF-binding proteins prolong the half-life of the IGFs and have been shown to either inhibit or stimulate the } \\
\text { growth promoting effects of the IGFs on cell culture. They alter the interaction of IGFs with their cell surface } \\
\text { receptors }\end{array}$ \\
\hline
\end{tabular}

\subsubsection{Apoptosis}

NF- $\kappa \mathrm{B} 1$ increased 1.51- and 1.31-fold for samples $\mathrm{P}_{48}$ and $\mathrm{C}_{48}$, respectively, then decreased at $120 \mathrm{~h}$. NF- $\kappa \mathrm{B}$ p65 (Rel A) decreased with time. TFAR15 was upregulated 2.75- and 2.56-fold for samples $\mathrm{P}_{48}$ and $\mathrm{C}_{48}$ compared to $\mathrm{A}_{48}$. $\mathrm{Bcl}-\mathrm{xL}$ was absent for samples $\mathrm{P}_{48}$ and $\mathrm{C}_{48}$. It was down-regulated 0.14-fold for sample $\mathrm{C}_{120}$ and decreased 0.90 -fold for sample $\mathrm{P}_{120}$ compared to $\mathrm{A}_{120}$. Bax isoform (alpha, beta, and delta) increased with time and also increased for samples $P_{120}$ and $C_{120}$ compared to $\mathrm{A}_{120}$.

\section{Discussion}

cDNA microarray technology was used to obtain a high-throughput of information on osteoblasts reaction to different titanium surface treatments. In order to have confidence in the results, we have performed the analysis of one sample $\left(\mathrm{C}_{24}\right)$ twice with two Genefilters. Although not identical, a comparison of results showed a good agreement of the gene expression values between the two filters.

It has been shown that surface roughness influenced the cell behaviour [19]. We have used XPS and AFM techniques to examine the surface properties of the treated Ti-6Al-4V surfaces [20]. A difference in roughness $\left(R_{\mathrm{a}}\right)$ between the passivated and the aged samples could only be observed at a small scale $\left(1 \mu \mathrm{m}^{2}\right)$. The area average $R_{\mathrm{a}}$ was about $0.99 \mathrm{~nm}(\mathrm{C}), 1.29 \mathrm{~nm}(\mathrm{P})$ and $0.56 \mathrm{~nm}$ (A). Therefore, at the cell level, the roughness could be considered as similar between samples and could not explain the differences in osteoblasts behaviour. These differences are then 
certainly due to the kinetics of ions release between surface treatments.

\subsection{Kinetics of genes modulation induced by the surface treatment $A$}

FAK and MAPK were down-regulated at $48 \mathrm{~h}$. Expression of these genes is related with integrin expression in a time course of events according to the Pathway 1 [21]

$$
\begin{aligned}
& \text { Integrins } \rightarrow \text { FAK } \rightarrow \text { MAPK } \rightarrow \text { c-jun and c-fos } \\
& \quad \rightarrow \text { Proliferation } \rightarrow \text { Differentiation (Pathway 1). }
\end{aligned}
$$

It has been demonstrated that osteoblasts cultured on Ti-6Al-4V produce FAK and MAPK within $24 \mathrm{~h}$ [22]. According to our results, down-regulation of FAK and MAPK at $48 \mathrm{~h}$ would not contradict the Pathway 1, especially if integrins were not modulated which was the case at $48 \mathrm{~h}$. c-jun expression of osteoblasts cultured on Ti-6Al-4V was also shown to be expressed before c-fos [22]. In our experiment, we noted a down-regulation of c-jun and an up-regulation of c-fos at $48 \mathrm{~h}$, which is then in accordance with the time course of events for c-jun and c-fos expression. It is then reasonable to admit that the osteoblast interaction with the surface treatment A followed the Pathway 1.

The expression of PTK decreased over time. Indeed, PTK has been showed to follow the Pathway 2 in macrophages when metal particles were present [23]

$$
\begin{aligned}
& \text { Surface membrane receptors binding particles } \\
& \quad \rightarrow \text { PTK and Serine/Threonine kinase } \\
& \quad \rightarrow \text { NF- } \kappa \text { B } \rightarrow \text { Releasing TNF/IL-6 (Pathway 2). }
\end{aligned}
$$

The osteoblasts also possess an inflammatory signaling response similar to Pathway 2 [24]. Following the decrease of PTK, we did not observe any modulation of NF- $\kappa \mathrm{B}$ or IL-6. It is possible that either the concentration of metal ions released from the aged sample is unable to stimulate the PTK pathway in osteoblasts or the induced signal pathway is different between particles and ions.

Several genes involved in the apoptosis process [2527] such as TRAIL, TRAIL-R3, RANK, TRANCE, CSFs were not detected while NF- $\kappa \mathrm{B} 1$, NF- $\kappa \mathrm{B}$ p 65 , TFAR15 had their expression decreased. In addition, the up-regulation of $\mathrm{Bcl}-\mathrm{xL}$, which is an inhibitor of apoptosis [28], increased with time. Conversely, the expression of Bax, which can accelerate apoptosis [28], decreased with time. These results could indicate that the surface treatment $\mathrm{A}$ did not stimulate the activation of apoptosis at $120 \mathrm{~h}$. Therefore the survival of osteoblasts could be enhanced on the aged surface treatment. However, these results need to be confirmed by direct apoptosis measurement such as TUNEL assay.
Without the expression of NF- $\kappa \mathrm{B}$, or CSFs, osteoblasts are unable to secrete cytokines such as IL-1 or IL6 involved in the differentiation and apoptosis of osteoclasts $[25,26,29]$. This confirms the observation of IL-1 or IL-6 expressions not being detected in our experiment. Based on the genes studied in this experiment, no stimulating effect of osteoblasts on osteoclasts differentiation or activation through cytokine expression seems to be involved in the $120 \mathrm{~h}$ of this experiment.

\subsection{Comparison of gene expression with respect to the surface treatments $C, P, A$}

Considering the genes involved in signal transduction, FAK was up-regulated 4.25 -fold for sample $\mathrm{P}_{48}$ and 6.63-fold for sample $\mathrm{C}_{48}$ while MAPK6 was upregulated 2.59-fold for sample $\mathrm{C}_{48}$ compared to $\mathrm{A}_{48}$. For samples $\mathrm{P}_{48}$ and $\mathrm{C}_{48}$ c-jun increased and c-fos decreased compared to $\mathrm{A}_{48}$. In addition, c-jun decreased with time while c-fos increased in all samples. All these modulations seem to indicate that samples $\mathrm{P}$ and $\mathrm{C}$ delay the time course of gene expression in the Pathway 1 compared to the sample A. By extrapolating the time course of gene expression in the Pathway 1, there should be a decrease of cell proliferation for the samples $\mathrm{C}$ and $\mathrm{P}$ compared to $\mathrm{A}$. This is what we found in a previous study [14], however using a different cell line rendering direct comparison delicate. This delay in the gene expression time course could be due to the decrease of aluminium ions being released by the surface treatment A [12] as it has been suggested that aluminium may alter the timing/regulation of the proliferation/differentiation transition point [30].

The expression of PTK9 was differentially modulated according to the surface treatments with an up-regulation for $\mathrm{C}_{48}$ and $\mathrm{P}_{48}$ compared to $\mathrm{A}_{48}$. In our previous work [11], we showed that the surface treatment $\mathrm{C}$ releases the highest amount of metal ions followed by the surface treatment $\mathrm{P}$ then the surface treatment $\mathrm{A}$. Lending evidence that the up-regulation of PTK followed exactly the same classification. The up-regulation of PTK was then directly related to the amount of ions released. According to the Pathway 2, the surface treatment A would then be more favourable by inducing less inflammatory reaction than the surface treatment $\mathrm{P}$ or C.

Recently, it has been demonstrated that Ti particles induce osteoblast apoptosis [6]. Despite osteoblast reaction to particles and ions may be different, we investigated the possibility of apoptosis induced also by ions. In the present study, no modulation of $\mathrm{Bcl}-\mathrm{xL}$ was detected for samples $\mathrm{P}_{48}$ and $\mathrm{C}_{48}$ compared to $\mathrm{A}_{48}$, while it was down-regulated for $\mathrm{P}_{120}$ and $\mathrm{C}_{120}$ compared to $\mathrm{A}_{120}$. On the other hand, the gene expression of Bax isoform (alpha, beta, and delta) increased with time. Osteoblast apoptosis could then be initiated from the 
high ratio of Bax to Bcl-xL. Based on these observations, osteoblasts may undergo more apoptosis on the surface treatment $\mathrm{P}$ and the $\mathrm{C}$ at $120 \mathrm{~h}$ than on the surface treatment $\mathrm{A}$ as a result of increased apoptotic factors expression.

Based on the genes selected in this study, we propose a general pathway of cell reaction according to the surface treatments used:

(1) Metal ion release changes the time course of gene expression in the FAK pathway (Pathway 1).

(2) Once the accumulation of metal ions released from the Ti surface exceeds a threshold value, cell growth is diminished and the apoptosis process may be activated.

(3) Metal ion release upregulates PTK (Pathway 2).

(4) The expression of Bcl-2 family and Bax may suggest that metal ions induce the apoptosis process.

\section{Conclusions}

The significant gene expression of collagen, FAK, MAPK, FGF-5, IGF-I and Bcl-xL demonstrated that primary human osteoblastic cells were active on the aged Ti-6Al-4V implants.

Although several apoptotic genes were expressed during the test, none of them continuously increased with time, except Bax, which suggests that Bax plays a significant role in the effects of metal ions on apoptosis.

Considering the experimental design, it has been found that most of the significant modulation took place before $48 \mathrm{~h}$. Therefore, to determine the critical point of gene expression in the different pathways future genomic biocompatibility testing should be performed before $48 \mathrm{~h}$ following cell seeding.

Finally, the developed surface treatment A seems to increase Ti-6Al-4V biocompatibility. This is highlighted by the lower impact of this treatment on the different pathways studied, by the lower inflammatory reaction, as well as by the lower induced osteoblast apoptosis compared to the surface treatment $\mathrm{C}$ and $\mathrm{P}$.

\section{Acknowledgements}

We would like to thank Davey Smith, MD for critical review of this manuscript. This study was financially supported by the Bioengineering Research Group of the School of Engineering Sciences at University of Southampton, the Orthopaedic Hospital of Lausanne and a grant from Leenaards Foundation (No. 309). This work was also supported by the Center for AIDS Research Genomics Core laboratories (AI36214) and the San Diego Veterans Affairs Healthcare System (JC).

\section{References}

[1] Puleo DA, Nanci A. Understanding and controlling the boneimplant interface. Biomaterials 1999;20:2311-21.

[2] Goodman SB, Fornasier VL. Clinical and experimental studies in the biology of aseptic loosening of joint arthroplasties and the role of polymer particles. In: St. John KR, editor. Particulate debris from medical implants: mechanisms of formation and biological consequences, ASTM STP 1144, Philadelphia: American Society for Testing and Materials, 1992. p. 27-37.

[3] Huiskes R, Weinans H, van Rietbergen B. The relationship between stress shielding and bone resorption around total hip stems and the effects of flexible materials. Clin Orthop 1992;274:124-34.

[4] Kadoya Y, Kobayashi A, Revell PA, Freeman MAR, Yamano Y. Relationship of wear particulate species and bone loss in failed total joint arthroplasties. 2nd combined ORS, San Diego, CA, 1995, p. 24.

[5] Bechtold JE, Soballe K, Lewis JL, Gustilo RB. The roles of implant motion and particulate polyethylene debris in the formation of an aggressive periprosthetic membrane. 41st ORS, Orlando, FL, 1995. p. 767.

[6] Pioletti DP, Takei H, Kwon SY, Wood D, Sung K-LP. The cytotoxic effect of titanium particles phagocytosed by osteoblasts. J Biomed Mater Res 1999;46:399-407.

[7] Pioletti DP, Takei H, Lin T, Van Landuyt P, Ma QJ, Kwon SY, Sung KLP. The effects of calcium phosphate cement particles on osteoblast functions. Biomaterials 2000;21:1103-14.

[8] Kwon SY, Takei H, Pioletti DP, Lin T, Ma QJ, Akeson WH, Wood DJ, Sung KL. Titanium particles inhibit osteoblast adhesion to fibronectin-coated substrates. J Orthop Res 2000;18:203-11.

[9] Takei H, Pioletti DP, Kwon SY, Sung KLP. TNF-a enhances functional modulation of osteoblast-like cells caused by titanium particles. J Biomed Mater Res 2000;52:382-7.

[10] Sun ZL, Wataha JC, Hanks CT. Effects of metal ions on osteoblast-like cell metabolism and differentiation. J Biomed Mater Res 1997;34:29-37.

[11] Browne M, Gregson PJ. Surface modification of titanium alloy implants. Biomaterials 1994;15:894-8.

[12] Browne M, Gregson PJ, West RH. Characterization of titanium alloy implant surfaces with improved dissolution resistance. J Mater Sci Mater Med 1996;7:323-9.

[13] Browne M, Gregson PJ. Effect of mechanical surface pretreatment on metal ion release. Biomaterials 2000;21:385-92.

[14] Ku CH, Pioletti DP, Browne M, Gregson PJ. Effect of different Ti-6Al-4V surface treatments on osteoblasts behaviour. Biomaterials 2002;23:1447-54.

[15] ASTM F. Medical devices; emergency medical services. Pennsylvania: American Society for Testing and Materials, 1999.

[16] Beresford JN, Gallagher JA, Poser JW, Russell RGG. Production of osteocalcin by human-bone cells-invitro-effects of $1,25(\mathrm{Oh}) 2 \mathrm{~d} 3$, 24,25(Oh)2d3, parathyroid-hormone, and glucocorticoids. Metab Bone Dis Relat Res 1984;5:229-34.

[17] Bidwell JP, Alvarez M, Feister H, Onyia J, Hock J. Nuclear matrix proteins and osteoblast gene expression. J Bone Miner Res 1998;13:155-67.

[18] Stein GS, Lian JB, Stein JL, Van Wijnen AJ, Montecino M. Transcriptional control of osteoblast growth and differentiation. Physiol Rev 1996;76:593-629.

[19] Boyan BD, Hummert TW, Kieswetter K, Schraub D, Dean DD, Schwartz Z. Effect of titanium surface characteristics on chondrocytes and osteoblasts in vitro. Cells Mater 1995;5:323-34.

[20] $\mathrm{Ku} \mathrm{CH}$. An investigation into the surface properties and biological performance of treated $\mathrm{Ti}-6 \mathrm{Al}-4 \mathrm{~V}$ alloy. $\mathrm{PhD}$. thesis, Engineering Materials, University of Southampton, 2001. 
[21] Cowles EA, Brailey LL, Gronowicz GA. Integrinmediated signaling regulates AP-1 transcription factors and proliferation in osteoblasts. J Biomed Mater Res 2000;52: 725-37.

[22] Krause A, Cowles EA, Gronowicz G. Integrin-mediated signaling in osteoblasts on titanium implant materials. J Biomed Mater Res 2000;52:738-47.

[23] Nakashima Y, Sun DH, Trindade MCD, Maloney WJ, Goodman SB, Schurman DJ, Smith RL. Signaling pathways for tumor necrosis factor-alpha and interleukin-6 expression in human macrophages exposed to titanium-alloy particulate debris in vitro. J Bone Jt Surg Am 1999;81A:603-15.

[24] Glant TT, Jacobs JJ. Response of three murine macrophage populations to particulate debris: bone resorption in organ cultures. J Orthop Res 1994;12:720-31.

[25] Jilka RL, Weinstein RS, Bellido T, Parfitt AM, Manolagas SC. Osteoblast programmed cell death (apoptosis): modulation by growth factors and cytokines. J Bone Miner Res 1998;13: 793-802.
[26] Schwarz EM, Lu AP, Goater JJ, Benz EB, Kollias G, Rosier RN, Puzas JE, O'Keefe RJ. Tumor necrosis factor-alpha/nuclear transcription factor-kappa B signaling in periprosthetic osteolysis. J Orthop Res 2000;18:472-80.

[27] Suliman A, Lam A, Datta R. Intracellular mechanisms of TRAIL: apoptosis through mitochondrial-dependent and -independent pathways. Oncogene 2001;20:2122-33.

[28] Lynch MP, Capparelli C, Stein JL, Stein GS, Lian JB. Apoptosis during bone-like tissue development in vitro. J Cell Biochem 1998;68:31-49.

[29] Hofbauer LC, Khosla S, Dunstan CR, Lacey DL, Boyle WJ, Riggs BL. The roles of osteoprotegerin and osteoprotegerin ligand in the paracrine regulation of bone resorption. $\mathbf{J}$ Bone Miner Res 2000;15:2-12.

[30] Bellows CG, Heersche JN, Aubin JE. Aluminum accelerates osteoblastic differentiation but is cytotoxic in long-term rat calvaria cell cultures. Calcif Tissue Int 1999;65:59-65.

[31] Ho NC, Jia L, Driscoll CC, Gutter EM, Francomano CA. A skeletal gene database. J Bone Miner Res 2000;15:15254-64. 